\title{
Correlations between Seed Color and Nutritional Composition of Dry Bean
}

\author{
Ali Kahraman • Mustafa Önder
}

received: 30 May 2013, accepted: 8 July 2013

published online: 30 October 2013

(c) 2013 IFVC

doi: $10.5937 /$ ratpov50-3959

\begin{abstract}
Summary: This study was conducted to determine the relations between seed color (the L, a and b values) and nutritional composition of dry bean genotypes. A total of 39 dry bean genotype seeds which are widely grown in Turkey were used as material. Color tests were made with three replications on 50 seeds of each genotype by color meter. Significant and positive correlations were found between all the tested minerals ( $\mathrm{Ca}, \mathrm{B}, \mathrm{Cu}, \mathrm{Fe}, \mathrm{K}, \mathrm{Mg}, \mathrm{Mn}, \mathrm{Mo}$ and $\mathrm{P}$ ) at the level of $\mathrm{p}<0.01$. Ratio of protein showed a level of $\mathrm{p}<0.05$ positive correlation coefficient with $\mathrm{Cu}(0.239)$ and $\mathrm{P}(0.277)$. According to the correlation analysis, the color of the seed coat and cotyledon showed insignificant correlations with nutritional composition. For the present study, it can be concluded that the color of common bean seeds did not give sufficient information about mineral composition. Path analysis showed that copper $(\mathrm{Cu})$ and phosphorus $(\mathrm{P})$ were important nutrients at the statistically important level of $5 \%$ with the positive correlation values of 0.239 and 0.277 , respectively. These elements are important for increase of the protein ratio in common bean genotypes.

Key words: color, beans, composition, food quality, minerals, nutrition, Phaseolus vulgaris L., seeds
\end{abstract}

\section{Introduction}

Legumes are known as a rich protein source and are provided as a main nutrient in many regions of the world. They have an important place in human nutrition, especially in the dietary pattern of lowincome groups of people in developing countries. Legumes, considered as poor man's meat, are generally good sources of nutrients (Önder \& Babaoğlu 2001, Tharanathan \& Mahadevamma 2003, Shimelis \& Rakshit 2005). Food mineral content is one of the essential phenomena for man. One purpose of the breeding is to find the solution for micronutrient deficiencies. Seed mineral content might be under the effects of soil, cultural practices, climate and genetic structure. Common bean has a great diversity of phenotypes in terms of seed size, colors and mineral composition, exposing the rich genetic diversity among the species (Papa et al. 2005, Gonçalves Ceolin et al. 2007). Breeders should pay attention to the importance of bioconservation and biodiversity (Kahraman et al.

\footnotetext{
A. Kahraman* • M. Önder

University of Selcuk, Faculty of Agriculture, Department of Field Crops, 42075, Konya, Turkey

e-mail: kahramanali@selcuk.edu.tr
}

2012). A remarkable characteristic of common bean is a grand flexibility of seed coat and patterns. As it is well known, it exhibits a complicated genetic inheritance (McClean et al.2002, Bassett 2007) and is one of the main features in breeding programs. Color of bean seeds is created by the existence and content of flavonol glycosides, anthocyanins and condensed tannins (proanthocyanins) (Beninger \& Hosfield 2003, Gu et al. 2003a, Gu et al. 2003b, Aparicio et al. 2005a, Aparicio et al. 2005b). Seed nutrient contents are significant to assure food production and to realize the genetic, biochemical and physiological mechanisms supporting extra amounts of association of the main source compounds in the seeds, such as minerals (Coelho \& Benedito 2008).

Recently developed bean cultivars are continually being improved and emerged from the research centers, such as Ethiopian. The economic value of a new cultivar is related to its yield, rate of maturity, resistance to diseases, seed size, color,

\section{Acknowledgements:}

We are thankful to Selcuk University, Coordinator of BAP (Project number: 06401030) for their financial support and Assist. Prof. Dr. Hacer Çoklar and Res. Assist. Fatma Gökmen, who work for Selcuk University, Faculty of Agriculture, for their incontrovertible contributions. 
nutritional quality, cooking time, the flavor and texture of a cooked food. The selection criteria have usually been resistance to diseases, yields and rate of maturation, but much lesser nutritive quality (FSPT 2001) as it is also seen in Turkey (Kahraman \& Önder 2009). Path analysis is a useful tool that provides determination of the selection criteria for plant breeders (Önder 1995, Önder 1996, Önder \& Akçin 1996, Önder \& Şentürk 1996, Önder \& Babaoğlu 2001). From this point, the scientific researches need to be explained by their whole findings in terms of tested characteristics, relations between the features and direct and indirect effects of each component on the other properties.

The purpose of the present study was to determine effect of seed color on nutritional composition and path analysis for protein content of dry bean genotypes that are widely grown in Turkey. The research findings should allow us to select and specify the relations of mineral content and seed color of all studied genotypes.

\section{Materials and Methods}

Color of seed coat and cotyledon in a total of 39 dry bean genotypes (Table 1 ) that are widely grown in Turkey were determined. For each genotype, 50 seeds were used as test material with three replications by Minolta Hunter Lab Colorimeter. On each sample, the data was recorded as following: $\mathrm{L}$ (Lightness) = from black (0) to white (100); a (red-purple $=$ positive value and green-bluish $=$ negative value); $\mathrm{b}$ (yellow $=$ positive value and blue $=$ negative value). Mineral contents $(\mathrm{Ca}, \mathrm{B}, \mathrm{Cu}, \mathrm{Fe}$, $\mathrm{K}, \mathrm{Mg}, \mathrm{Mn}, \mathrm{Mo}, \mathrm{P}$ and $\mathrm{Zn}$ ) were determined by ICP-AES (Varian Vista Model) while protein ratio was determined by Kjeldahl device.

The means of tested characteristics of the genotypes were used in a different study which is entitled as "Some Quality Properties Relationships of Common Bean Genotypes That Grown in Konya Province" as an oral presentation in Hatay/ Turkey (Kahraman \& Önder 2009).

Correlation analyses were made by JUMP computerized statistical program. Path analysis was made using the TARIST program. Correlation coefficients were calculated to test the connection between seed color and other analyzed characteristics in the first step. Then, correlation was calculated between all tested characteristics.

Path coefficients were separated into direct and indirect effects using protein ratio as the dependent variable.

Table 1. Collection number (№), place (source) of collection and local names of tested dry bean genotypes

\begin{tabular}{|l|l|l|l|l|l|}
\hline$№$ & Source & Local name & № & Source & Local name \\
\hline 1 & Başarakavak & Horoz & 21 & Beyşehir 1 (Göçü Village) & Horoz Fasulye \\
\hline 2 & Başarakavak & Sarıkız & 22 & Seydişehir 1 & Sıra Fasulye \\
\hline 3 & Başarakavak & Kanada & 23 & Ilgın 1 (Beykonak) & Beyaz Horoz Fasulye \\
\hline 4 & Çumra & Şeker $($ Bıyıklı) & 24 & Sarayönü 1 & Kanada Fasulyesi \\
\hline 5 & Çumra & Kırgız Çalısı & 25 & Sarayönü 2 (Bayramlı Village) & Amerikan Çalısı \\
\hline 6 & Çumra & Horoz & 26 & Yunak 2 & Üveynk (Veynk Fasulye) \\
\hline 7 & Çumra & Beyşehir Çalısı & 27 & Yunak 4 & Kanada Fasulyesi \\
\hline 8 & Çumra & Bombay (Bomba) & 28 & Çumra & Kırgız Yuvarlak \\
\hline 9 & Çumra & Kanada & 29 & Derbent 2 & Yuvarlak Barbunya \\
\hline 10 & Altınekin & Amerikan Kollu & 30 & Akşehir 4 & Dermason \\
\hline 11 & Altınekin & Sarnıç & 31 & Akşehir 5 (Sorkun Village) & Ayşe Kadın Fasulyesi \\
\hline 12 & Altınekin $($ Mantar Village) & Amerikan Çalısı & 32 & Akşehir 6 & Horoz Fasulye (Oturak) \\
\hline 13 & Konya (Center) & Gina & 33 & Akşehir 7 & Dermason (Oturak) \\
\hline 14 & Ereğli (Center) & Dermason & 34 & Kazım Karabekir & Kanada (Kara Yaprak) \\
\hline 15 & Ereğli (Center) & Horoz & 35 & Kazım Karabekir & Dermason (Kırgız) \\
\hline 16 & Kadınhanı 1 & Weihing & 36 & Eskişehir-Anadolu Agr.Res.Ins. & Akman 98* \\
\hline 17 & Kadınhanı 2 & Kanada & 37 & Eskişehir-Anadolu Agr.Res.Ins. & Eskişehir-855* \\
\hline 18 & Kadınhanı 3 & Akman98* & 38 & Erzurum- Atatürk University & Elkoca-2005* \\
\hline 19 & Derbent 1 & Amerikan (Beretta) & 39 & Erzurum- Atatürk University & Kantar-2005* \\
\hline 20 & Derbent 5 & Şeker & $*$ Certified line & \\
\hline
\end{tabular}




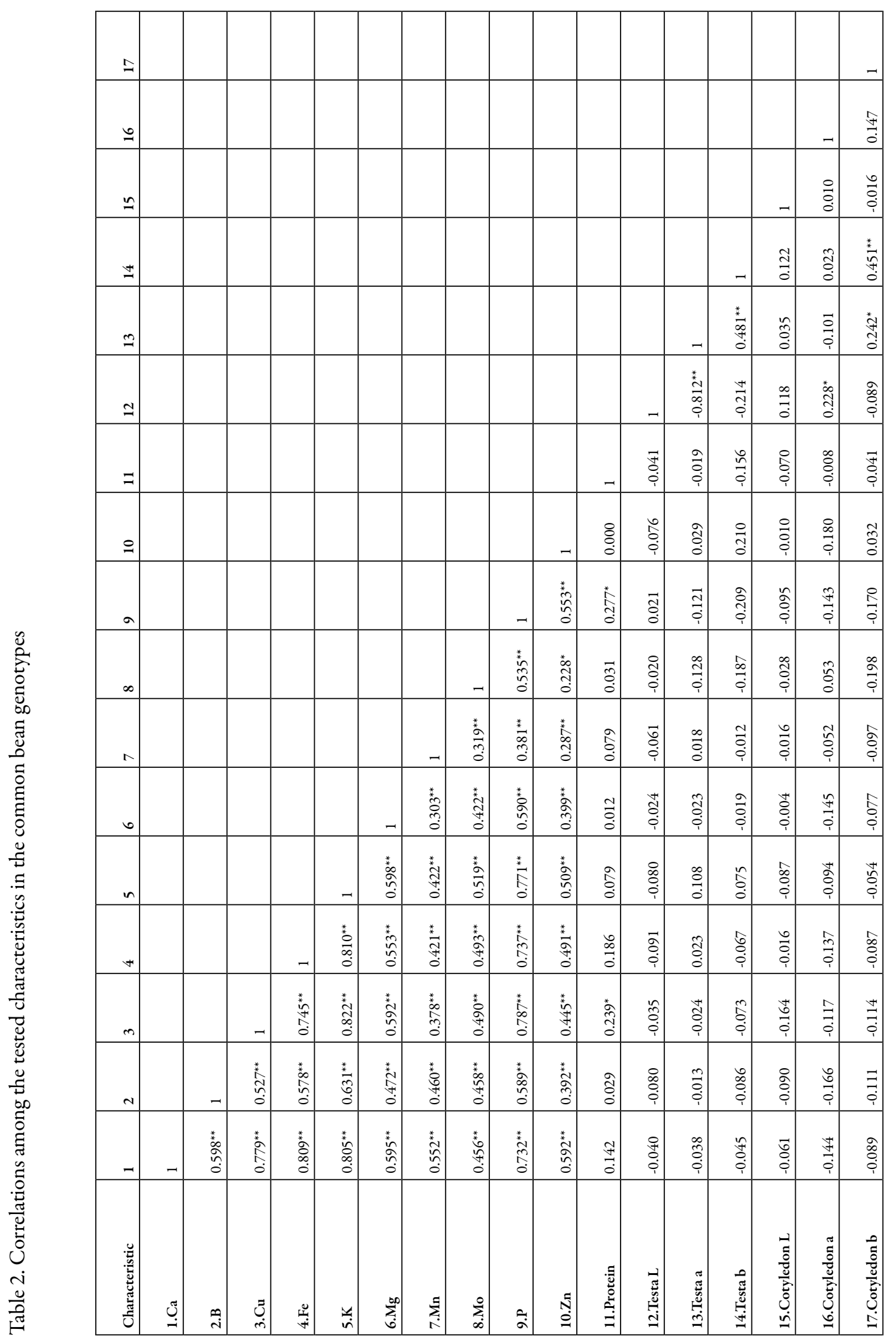




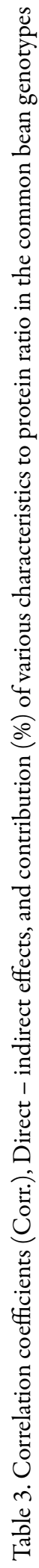

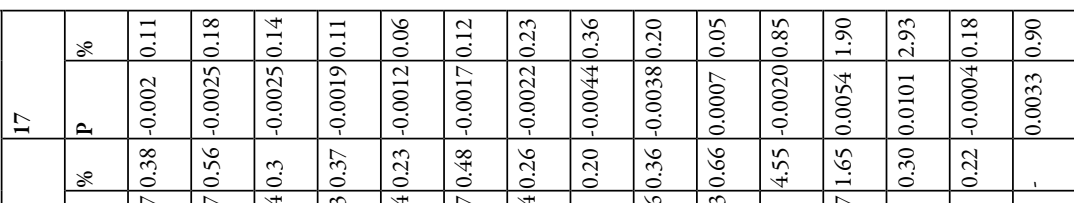

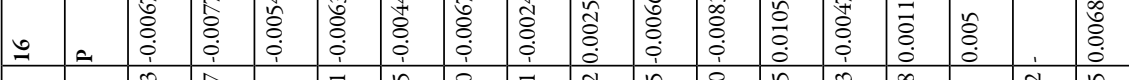

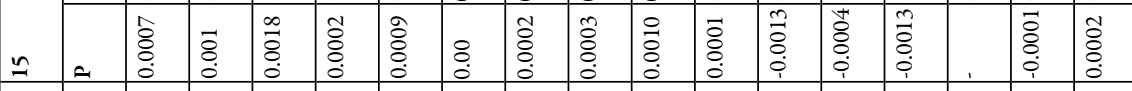

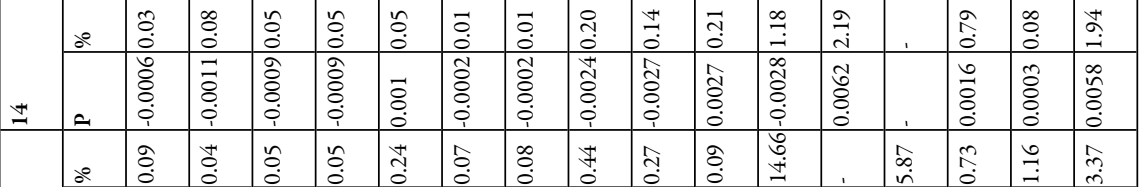

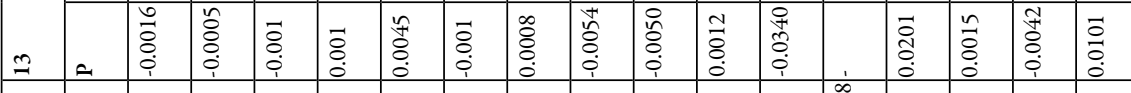

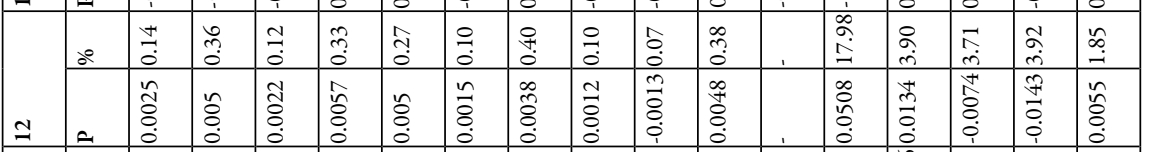

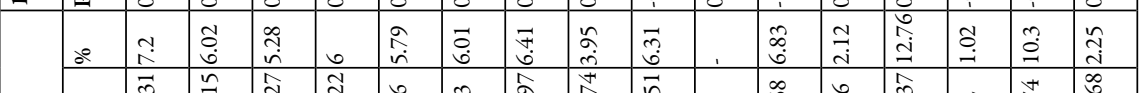

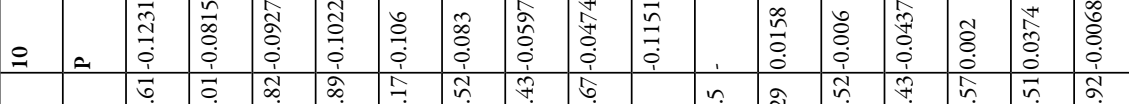

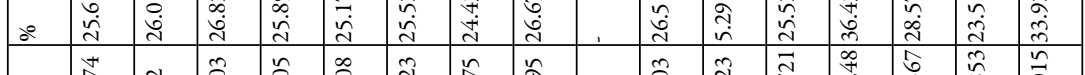

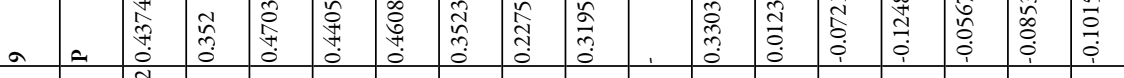

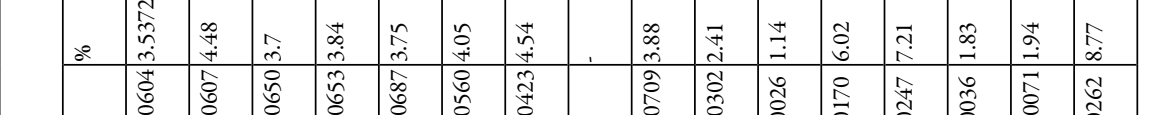

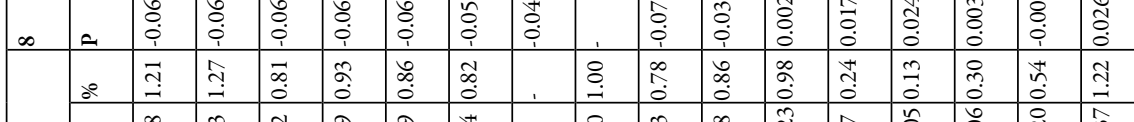

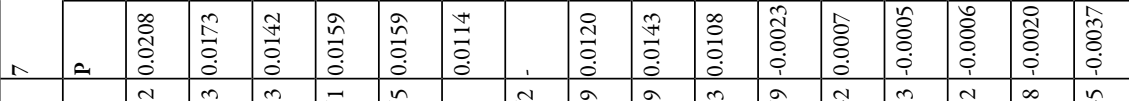

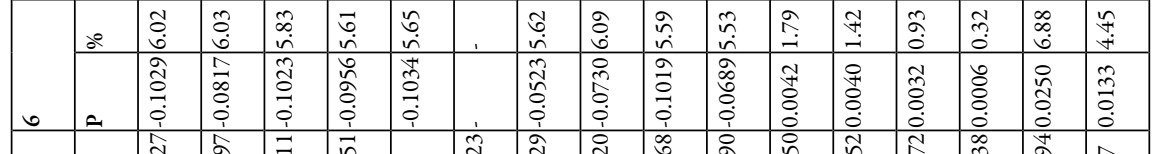

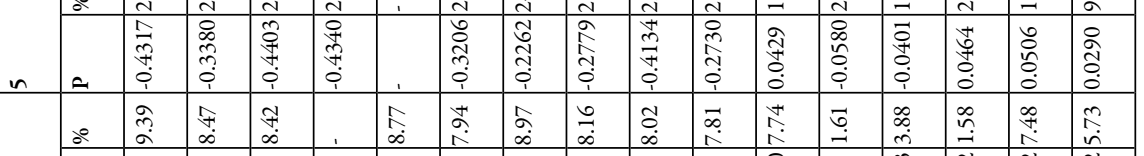

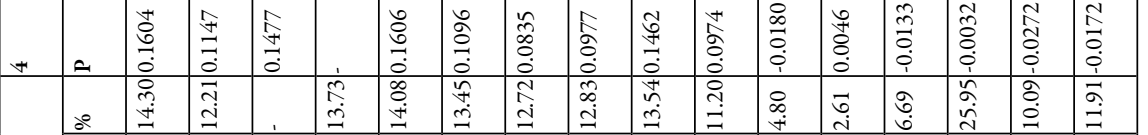

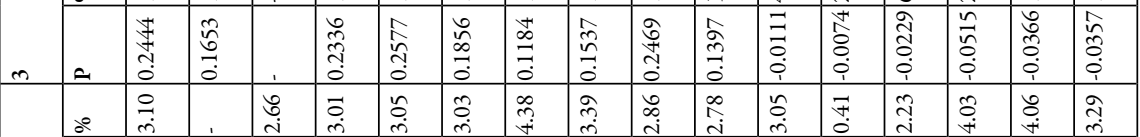

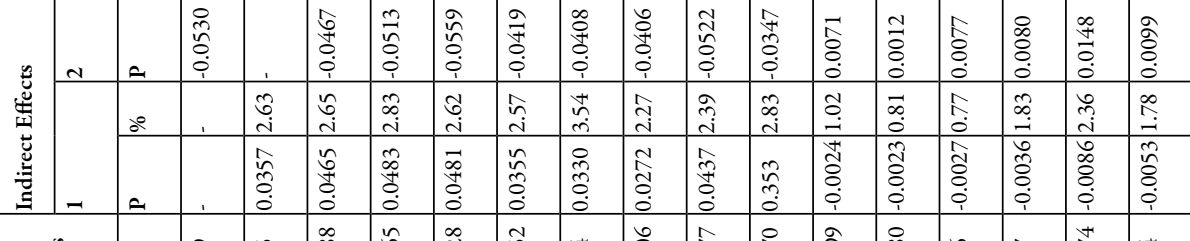

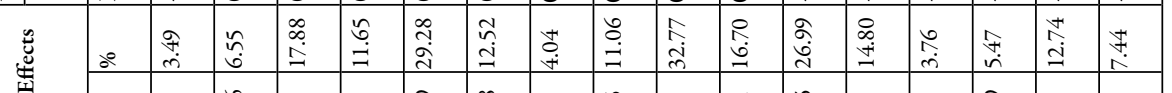

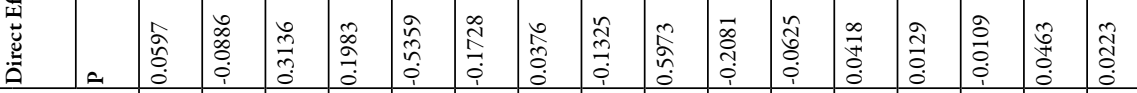

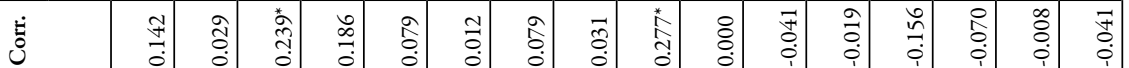

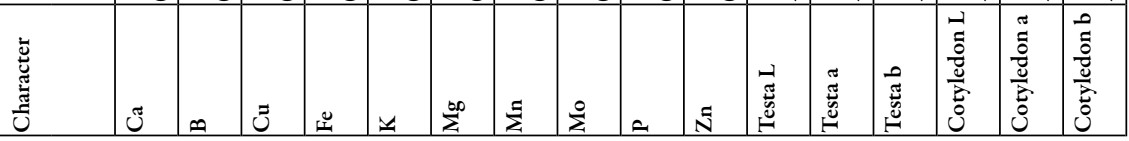




\section{Results and Discussion}

Protein ratio of the dry bean genotypes in the present study ranged from $20.11 \%$ to $28.59 \%$, while content of the analyzed minerals ranged as following: P: 0.09\%-0.51\%; K: 0.12\%-2.03\%; Ca: 0.01\%-0.19\%; Mg: 0.01\%-0.13\%; Fe: 2.02-53.83 ppm; Mn: 0.12-95.76 ppm; B: $1.03-16.10$ ppm, $\mathrm{Zn}$ : 3.10-30.88 ppm; Cu: 0.94-10.00 ppm; Mo: 0.00-16.54 ppm.

There were significant and positive correlations between all tested minerals $(\mathrm{Ca}, \mathrm{B}, \mathrm{Cu}, \mathrm{Fe}, \mathrm{K}, \mathrm{Mg}$, $\mathrm{Mn}, \mathrm{Mo}$ and $\mathrm{P}$ ) at the level of $\mathrm{p}<0.01$. Protein rate showed a level of $\mathrm{p}<0.05$ positive correlation coefficient with $\mathrm{Cu}(0.239)$ and $\mathrm{P}(0.277)$. Table 2 indicates correlation coefficients between all tested characteristics.

Correlation analysis showed that color of the seed coat and cotyledon has insignificant correlations with nutritional composition. Consequently, the color of common bean seeds did not provide enough information on the mineral composition.

According to the Path analysis, copper $(\mathrm{Cu})$ and phosphorus (P) were found as important nutrients at the statistically important level of $5 \%$ with the positive correlation values of 0.239 and 0.277 , respectively. Table 3 indicates the correlation coefficients, direct and indirect effects of tested characteristics on the protein ratio. It can be concluded that content of the K $(29.28 \%)$ and Testa L value (26.99) also showed a high level of direct effect on protein ratio.

The testa color ranged as following: $\mathrm{L}=50.98$ $88.41 ; \mathrm{a}=0.02-13.36$ and $\mathrm{b}=0.36-18.03$. The color of cotyledon ranged as following: 58.51-82.91; $\mathrm{a}=1.57$ 3.76 and $b=6.73-19.52$ respectively. Similarly, Shimelis \& Rakshit (2005) found these values as it is seen in the following line: $\mathrm{L}=28.82-73.97$; $\mathrm{a}=1.69$ 14.39 and $b=5.71-25.39$ respectively. Differences between the colors could be based on genetic bases, environment conditions, soil characteristics and cultural practices (Ceyhan et al. 2012).

Results of the present study suggest that selection based on increased protein ration should be based on the content of $\mathrm{Cu}$ and $\mathrm{P}$ in dry bean genotypes. In breeding programs, content of $\mathrm{K}$ and value of Testa $\mathrm{L}$ color could be also suggested to improve protein ratio due to their strong direct effects.

Present study showed similar data to previous researches. Dry bean contains some bioactive components connected with health benefits. However, some facts are still unknown, such as their role on chronic-degenerative diseases (Reynoso-Camacho et al. 2006). Duranti \& Gius (1997) reported that proteins are the major legume components and they have nutritional and functionalcharacteristics that emphasizequalitative and technological features. Gonzalez et al. (2006) stated that high yielded genotypes had higher protein ratio. Content of minerals in plant seeds varies in a wide range (Thompson \& Troeh 1973). Correlations between mineral compositions put forward parallel results that show that increasing of one mineral might increase content of the other minerals (Beebe et al. 1999). Nutritional values of the legumes are affected by many factors. Therefore, definition of common bean promoters would provide a more direct expression with potential energy savings for the plants (Coelho \& Benedito 2008, Önder \& Kahraman 2009).

Knowledge about nutritional values of the food should be one of the main purposes in breeding programs. Dry bean has high adaptation ability over the world and is an important source of food. Researchers need to determine the quality characteristics of the present genotypes. Present research implicated that there is a wide range among the local dry bean genotypes in terms of their nutritional features. In future, breeding programs may use local genotypes as parents, according to the results.

\section{References}

Aparicio-Fernandez, X., Yousef, G.G., Loarca-Pina, G., Mejia, E., \& Lila, M.A. (2005). Characterization of polyphenolics in the seed coat of Black Jamapa bean (Phaseolus vulgaris L.). J Agric Food Chem, 53(11), 4615-22. pmid:15913334

Aparicio-Fernández, X., Manzo-Bonilla, L., \& Loarca-Piña, G. (2005). Comparison of antimutagenic activity of phenolic compounds in newly harvested and stored common beans Phaseolus vulgaris against aflatoxin B1.J Food Sci,70, 73-78.

Basset, M.J. (2007). Genetics of seed coat color and pattern in common bean. Plant Breeding Reviews, 28, 239-315.

Beebe, S., Gonzalez, A.V., \& Rengifo, J. (1999). Research on trace minerals in common bean. In: Improving Human Nutrition Through Agriculture: The Role of International Agricultural Research,, 1999. IFPRI.

Beninger, C.W., \& Hosfield, G.L. (2003). Antioxidant activity of extracts, condensed tannin fractions, and pure flavonoids from Phaseolus vulgaris L. seed coat color genotypes. J Agric Food Chem, 51, 7879-7883. pmid:12502377

Ceyhan, E., Kahraman, A., \& Önder, M. (2012). The impacts of environment on plant products. International Journal of Bioscience, Biochemistry and Bioinformatics, 2(1), 48-51.

Coelho, C.M.M., \& Benedito, V.A. (2008). Seed development and reserve compound accumulation in common bean ( $P h a-$ seolus vulgaris L.). Seed Science and Biotechnology, 2(2), 42-52.

Duranti, M., \& Gius, C. (1997). Legume seeds: protein content and nutritional value. Field Crops Research, 53, 31-45.

Food Science and Post-harvest Technology (FSPT). (2001). Research strategy. Addis Ababa, Ethiopia: Ethiopian Agricultural Research Organization (EARO).

Gonçalves, C.A.C., Gonçalves-Vidigal, M.C., Soares, V.F.P., Vinícius, K.M., Gonela, A., \& Alberto, S.C. (2007). Genetic divergence of the common bean (Phaseolus vulgaris L.) group Carioca using morpho-agronomic traits by multivariate analysis. Hereditas, 144(1), 1-9. pmid:17567434 
Gonzalez, A.M., Monteagudo, A.B., Casquero, P.A., Ron, A.M., \& Santalla, M. (2006). Genetic variation and enviromental effects on agronomical and commercial quality traits in the main European market classes of dwarf dry bean. Field Crops Research, 95, 336-347.

Gu, L., Kelm, M.A., Hammerstone, J.F., Beecher, G., Holden, J., Haytowitz, D., \& Prior, R.L. (2003). Screening of foods containing proanthocyanidins and their structural characterization using LC-MS/MS and thiolytic degradation. J Agric Food Chem, 51(25), 7513-21. pmid:14640607

Gu, L., Kelm, M.A., Hammerstone, J.F., Zhang, Z., Beecher, G., Holden, J., . . Prior, R.L. (2003). Liquid chromatographic/ electrospray ionization mass spectrometric studies of proanthocyanidins in foods. J Mass Spectrom, 38(12), 1272-80. pmid:14696209

Kahraman, A., \& Önder, M. (2009). Some quality properties relationships of common bean genotypes that grown in konya province. In: Türkiye VIII. Tarla Bitkileri Kongresi, 2009-1019.314-317.

Kahraman, A., Önder, M., \& Ceyhan, E. (2012). The importance of bioconservation and biodiversity in Turkey.International Journal of Bioscience, Biochemistry and Bioinformatics, 2(2), 95-99.

McClean, P.E., Lee, R.K., Otto, C., Gepts, P., \& Bassett, M.J. (2002). Molecular and phenotypic mapping of genes controlling seed coat pattern and color in common bean (Phaseolus vulgaris L.). J Hered, 93(2), 148-52. pmid:12140276

Önder, M. (1995). Kışlık kolzada dane ve yağ verimi ile bazı verim komponentlerinin korelasyonu ve path analizi. SÜ Ziraat Fakültesi Dergisi, 8(10), 39-49.

Önder, M. (1996). Soya dane, yağ ve protein verimi ile bazı ve- rim unsurları arasındaki ilişkiler. SÜ Ziraat Fakültesi Dergisi, 10(12), 7-16.

Önder, M., \& Akçin, A. (1996). M3 generasyonundaki mutant fasulye hatlarında verim ve bazı verim öğelerinin korelasyonu ve path analizi. SÜZ Ziraat Fakültesi Dergisi, 9(11), 83-90.

Önder, M., \& Şentürk, D. (1996). Ekim zamanlarının bodur kuru fasulye çeșitlerinde dane ve protein verimi ile verim unsurlarına etkisi. $S \dot{U}$ Ziraat Fakültesi Dergisi, 10(13), 7-18.

Önder, M., \& Babaoğlu, M. (2001). Interactions amongst grain variables in various dwarf dry bean (Phaseolus vulgaris $\mathrm{L}$.) cultivars. Journal Agronomy and Crop Science, 187, 19-23.

Önder, M., \& Kahraman, A. (2009). Antinutritional factors in food grain legumes. In 1st International Symposium on Sustainable Development, June 8-10, Sarajevo. (pp. 40-44).

Papa, R., Acosta, J., Delgado-Salinas, A., \& Gepts, P. (2005). A genome-wide analysis of differentiation between wild and domesticated Phaseolus vulgaris from Mesoamerica. Theor Appl Genet, 111(6), 1147-58. pmid:16142467

Reynoso-Camacho, R., Ramos-Gomez, M., \& Loarca-Pina, G. (2006). Bioactive components in common beans (Phaseolus vulgaris L.). In Advances in Agricultural and Food Biotechnology. (pp. 217-236).

Shimelis, E.A., \& Rakshit, S.K. (2005). Proximate composition and physico-chemical properties of improved dry bean (Phaseolus vulgaris L.) varieties grown in Ethiopia. LWT--Food Science and Technology, 38(4), 331-338.

Tharanathan, R.N., \& Mahadevamma, S. (2003). Grain legumes-a boon to human nutrition. Trends in Food Science \& $T$ chnology, 14(12), 507-518.

Thompson, L.M., \& Troeh, F.R. (1973). Soil and soil fertility. (pp. 1-495). New York: McGraw-Hill Book Compony.

\title{
Korelacije izmedu boje semena i nutritivnog sastava pasulja
}

\author{
Ali Kahraman • Mustafa Önder
}

Sažetak: Ova studija je sprovedena kako bi se utvrdila povezanost između boje semena (L, a i b vrednosti) i nutritivnog sastava genotipa pasulja. Kao materijal korišćeno je seme od ukupno 39 genotipova pasulja koji se uzgajaju širom Turske. Kolor testovi su sprovedeni u tri ponavljanja sa po 50 semena svakog genotipa na kolor metru. Značajne i pozitivne korelacije ostvarene su između svih ispitanih minerala ( $\mathrm{Ca}, \mathrm{B}, \mathrm{Cu}, \mathrm{Fe}, \mathrm{K}, \mathrm{Mg}, \mathrm{Mn}, \mathrm{Mo}$ i P) na nivou od p<0,01. Udeo proteina pokazao je nivo $\mathrm{p}<0,05$ pozitivnog korelacijskog koeficijenta sa $\mathrm{Cu}(0,239)$ i $\mathrm{P}(0,277)$. Prema analizi korelacija, boja semenjače i kotiledona nije imala značajne korelacije sa nutritivnim sastavom. Ovom studijom može se zaključiti da boja semena pasulja nije dala dovoljno informacija o mineralnom sastavu. Path analiza je pokazala da su bakar $(\mathrm{Cu})$ i fosfor $(\mathrm{P})$ važni nutrijenti na nivou $5 \%$ statističke značajnosti uz pozitivne korelacijske vrednosti od 0,239 odnosno 0,277 . Ovi elementi su važni za povećanje udela proteina u genotipovima pasulja.

Ključne reči: boja, ishrana, kvalitet hrane, minerali, pasulj, Phaseolus vulgaris L., sastav, seme 